\section{Experience and nature}

\section{John Dewey}

New York: Dover Publications, first published in 1925 based on the Paul Carus lectures delivered by Dewey; republished in 1958 after a substantial revision undertaken by Dewey himself in that year.

$F^{\circ}$ some the name John Dewey conjures up either the system for library categorisation (the Dewey decimal system) or, and rather undeservedly, a link with the experiential education movement of the 1960s (e.g., learning by doing), later to be rather derisively called 'the play way of education' (based as it supposedly was on Dewey's child-centred and project-based learning principles).

Next year will be the 100th anniversary of the publication of Dewey's Democracy and education: an introduction to the philosophy of education. There are a number of international conferences planned, so it is timely to revisit the work of John Dewey more generally.

Experience and nature $(1925,1958)$ provides in one book a very clear encapsulation of the thinking behind Dewey's model of teaching, learning and problem solving. It is thus a good starting point for anyone not familiar with Dewey's work and leads naturally on to further explorations.

At times the language can be somewhat archaic to modern ears and the examples given often repetitive but nonetheless this is a classic text for anyone interested in understanding Dewey's core theory and ideas which get developed in subsequent works.

Dewey's influence on modern educational and psychological thinking has been profound (see Argyris 1982, 1993; Argyris \& Schön 1974;, Robinson 1993; as well as the Problem Based Learning approach, interactionist/ecosystemic positions, consultation and problem solving).

Dewey, like Vygotsky, saw the development of thinking as essentially a social one mediated through language. An individual's thinking only makes sense when seen as being an integrated part of their society. Society equally has little meaning apart from its representation in the lives of its individuals.

Dewey argued that human 'experience' in the real world was the basis for knowledge, awareness and action (e.g., the thought-action-thought-action cycle). Dewey's construction of 'experience' represented an enormous breakthrough in empiricism, as the notion encompassed much more than just passive sensory exposure and that the world was singly mind-dependent. Dewey introduced the important role that action plays in the development of thought.
Experience is seen as an iterative process of active inquiry involving a purposeful engagement between the individual and the material world. But it is not unidirectional and as the person enacts upon the world it is changed, which leads in turn to transformations to the constructions the person has made and so on.

Such an active inquiry process is usually triggered by a problem or dilemma that the material world presents to the individual (e.g., working out what is going on, working out how to act in response to it and ultimately remaking that context). Dewey called these the 'mundane' problems of the real world.

Dewey stressed that humans show a combination of perception and activity as they try to understand things and impose structure on them (e.g., developing a theory of action, theorising, acting, reflecting, altering, testing out and so on).

However, this combination only works because of action and its effects (as well as thinking and theorising). Therefore thought is not separate to and from action; both are parts of the same process. To argue the contrary leads to incoherence and what Dewey referred to as 'magical thinking

The book brings a pragmatic optimism by suggesting that humans have the capacity to improve the world they live in for themselves and those with whom they interact. This is one of the cornerstones of applied psychology.

For Dewey this was not an arbitrary process but one that acknowledged the co-dependency of thought and action within the material world guided by the laws of physics and logic.

Experience and nature $(1925,1958)$ is highly recommended to all students of education, psychology and those practitioners and academics interested in how people make sense of their world, solve problems, make decisions and change. 


\section{References}

Argyris, C. (1982). Reasoning, learning and action. San Francisco, CA: Jossey-Bass.

Argyris, C. (1993). On the nature of actionable knowledge. The Psychologist, 16, $29-32$.

Argyris, C. \& Schön, D. A. (1974). Theory in practice. San Francisco, CA: Jossey-Bass.

Robinson, V. (1993). Problem-based methodology: research for the improvement of practice. Oxford: Pergamon Press

\section{Dr Jeremy Monsen}

Tri-borough Principal Educational Psychologist

Tri-borough Educational Psychology Service (Hammersmith \&

Fulham, Kensington \& Chelsea, and Westminster)

jeremy.monsen@,virgin.net 